$1-1-2005$

\title{
Environmental Justice in a Dryland Democracy: A Comment on Water Basin Institutions
}

Eileen Gauna

University of New Mexico - School of Law, gauna@law.unm.edu

Follow this and additional works at: https://digitalrepository.unm.edu/law_facbookdisplay

Part of the Law Commons

\section{Recommended Citation}

Gauna, Eileen. "Environmental Justice in a Dryland Democracy: A Comment on Water Basin Institutions." Wet Growth, Should Water Law Control Land Use? (2005): 171-199. https://digitalrepository.unm.edu/law_facbookdisplay/61

This Book Chapter is brought to you for free and open access by the School of Law at UNM Digital Repository. It has been accepted for inclusion in Faculty Book Display Case by an authorized administrator of UNM Digital Repository. For more information, please contact amywinter@unm.edu. 


\title{
Chapter Five
}

\section{Environmental Justice in a Dryland Democracy: A Comment on Water Basin Institutions}

\author{
Eileen Gauna
}

\section{Introduction}

Prof. Janet Neuman, in Dusting Off the Blueprint for a Dryland Democracy: Incorporating Watershed Integrity and Water Availability Into Land Use Decisions (Dryland Democracy), puts forth an elegant case for reconsideration of John Wesley Powell's 1878 principles to develop the arid westem United States. ${ }^{1}$ The thrust of her proposal is the establishment of basinwide institutions with consolidated regulatory authority. In this context, basin is assumed to be an entire water system, from the point of its origin; it would include all supporting tributaries and the associated groundwater and land uses that affect that system. As such, a water basin could include westem river systems that span several states. The project would involve consolidating authority from numerous federal, tribal, and sub-federal authorities with jurisdiction over water allocation, pollution control, and land use decisions that affect the basins' ecosystems.

1. John Wesley Powell, Report on the Lands of the Arid Region of the United States, Wrth a More Detalled Account of the Lands of Utah, H.R. Exec. Doc. No. $45-73$ (2d Sess. 1878). See also Wallace Stegner, Beyond the Hundredth Meridian: John Wesley Powell AND THE SECOND OPENING OF THE West (1954). 
In support of Professor Neuman's proposal are portions of Powell's blueprint that are most pertinent to the oversettled arid West of the 21st century. Powell's early vision might seem utopian to some, and the political difficulty of accomplishing the task of consolidating authority far too unrealistic. Nonetheless, Professor Neuman argues that this approach might be the only ecologically viable way to manage water resources and, despite the difficulty of getting there, it is an approach that must be seriously considered. Otherwise, the integrity of our West's precious water resources will continue on the path to inevitable environmental destruction caused by overuse, aggressive plumbing (bringing water from distant basins through engineering), and water-intensive land uses (such as uncontrolled growth and excessive groundwater pumping) that affect the availability, flow, and quality of surface waters. Our present framework of fragmented jurisdiction cannot really address the multiple demands on the West's rivers and lakes, and our legacy of acrimonious water wars will just get worse. In short, she argues, a radically different alternative is not utopian; it is necessary. It is difficult to disagree with that proposition.

That said, however, there are obvious complications in dusting off Powell's blueprint, primarily because it was designed and written as a forward looking document, a plan to develop the West in a manner intensely mindful of the area's aridity. As it turned out, Powell's advice was ignored, and as Professor Neuman acknowledges, in many respects it is simply too late to reverse engineer the damage. Instead, the fundamental principles in Powell's 1878 blueprint must be employed in the 21 st century to do a much more difficult job. Not only is the arid West ecologically distressed by rapid urbanization and inappropriate land uses - a condition described and explained in Dryland Democracy - but the West is also fraught with existing social, economic, and environmental inequities. As Professor Neuman discusses, some of these inequities are themselves the result of the skewed economies and the resulting environmental damage to water basins. In particular, the extensive plumbing allows entrenched vested interests, notably highly subsidized agribusiness and growing municipalities, to appropriate water from great distances. As a result, many rural areas and indigenous communities, as well as farm workers and immigrant communities, are often left with poor quality, scarce, polluted, and high salinity waters.

This comment to Dryland Democracy will expand upon the theme of social costs, exploring how Professor Neuman's basic proposal-water basin institutions with centralized authority - might address some of these inequities. There are not only serious environmental justice issues 
that must be addressed by a water basin institution, but there are also special complications that would arise during the initial process of consolidating authority. Before that discussion proceeds, however, a brief history of the environmental justice movement is set forth for the benefit of readers who might not be familiar with this sociopolitical development. Following that introduction is a discussion of water-related environmental justice issues that a water basin institution might be expected to address.

This chapter takes a slightly different approach geographically, drawing upon examples taken largely from the Southwest instead of the Pacific Northwest, the geographic region that Professor Neuman uses to draw many examples in Dryland Democracy. In part, this approach is to allow the reader to better compare and appreciate the regional differences throughout the arid West. But in addition, the ecological problems in the Southwest are more dire simply because water is more scarce. For example, in 15 minutes, more water flows down the Columbia River in Oregon than flows in the entire state of New Mexico in a year. ${ }^{2}$ This situation means that the conflicts among interests that give rise to water disputes are all the more fierce. ${ }^{3}$ Moreover, due to the scarcity of surface waters, there are fewer opportunities for diversions from other rivers or lake systems, leaving excessive pumping of groundwater to quench the thirst of growing urban centers a more attractive alternative. Thus, land use issues are particularly important in protecting lake and river ecosystems. In addition, as recently noted by Prof. Dan Tarlock, the type of agricultural practices in the northern part of New Mexico and southern Colorado is atypical. Instead of the large-scale farming practices of agribusinesses, farming in this area is organized around acequias, a communal sharing of ditch irrigation systems that is closely tied to Hispanic cultural traditions. ${ }^{4}$ This system is fiercely de-

2. Alletta Belin et al., Taking Charge of Our Water Destiny: A Water Management Policy Guide for New Mexico in the 21st Century 33 (1000 Friends of New Mexico 2002).

3. For an enlightening example of one interstate dispute, see G. EmLEN HaLl, High and Dry: The Texas-New Mexico Struggle for the Pecos RIVER (2002).

4. A. Dan Tarlock, Remarks at the Natural Resources Journal Symposium, University of New Mexico (Apr. 12, 2003). See also Ruben O. Martinez, Social Action Research, Bioregionalism, and the Upper Rio Grande, in $\mathrm{CHI}-$ cano Culture, Ecology, Politics: Subversive Kin 58 (Devon G. Peña ed., 1998). 
fended not only because of the water, but because it is intrinsically tied to communal values and cultural identity.

Although the Southwest shares much in common with the arid West generally, there are additional challenges present in the Southwest that can be used as a lens to explore the environmental justice implications of basinwide management. An exhaustive discussion of these diverse issues is not possible in a comment of this scope. Instead, the environmental justice issues are raised with a view toward advancing the discussion of an alternative system based upon consolidated authority at the basin level, and how water-dependent communities with meager resources and little political influence might fare under such a system.

\section{Environmental Justice Issues Under the Current System}

"Environmental justice" is a term used to self-consciously describe a political movement that is centered around grassroots organizing with a mission to address both the unequal distribution of environmental burdens and amenities, and the impediments to fair process that serve to exclude low-income and communities of color, tribal governments, and indigenous people from important decisions about their environments and their lives. Environmental justice is tied to a broader mission of social and economic justice. Although organizing begins at the local level and is guided by principles of environmental justice that were collectively adopted in $19911^{5}$ local organizations often affiliate with networks ${ }^{6}$ and address regional, national, and international issues as well.

Often, the term "environmental justice" is used as a catchphrase to describe the conditions that gave rise to the movement. For example, individuals that are familiar with the phrase often associate environmental justice with controversies over the siting of large hazardous waste facilities, because those were the first high-profile issues that caught the public's attention. ${ }^{7}$ Of course, indigenous communities, people of

5. Proceedings, The First National People of Color Environmental LEADERSHIP Summit xiii (Oct. 24-27, 1992) (Principles of Environmental Justice), available at http://www.hawo.org/pdf/02NuclearRacism.pdf (last visited June 19, 2003).

6. Some of the networks include the Asian Pacific Environmental Network, the Southwest Network for Economic and Environmental Justice, the Indigenous Environmental Network, the African-American Environmental Justice Network, and the National Black Environmental Justice Network.

7. See Clifford Rechtschaffen \& Eileen Gauna, Environmental Justice: LAw, Policy, ANd Regulation 3-6 (2002) for a descrip- 
color, and the poor are also disparately located near constellations of other risk-producing and noxious land uses, such as concentrated animal feeding operations, mining operations, chemical plants, refineries, power plants, nuclear plants and storage facilities, steel mills, landfills, sewage treatment facilities, military bases, airports, and Superfund sites. ${ }^{8}$ For example, one can find several poor African-American communities interspersed among the petrochemical plants along the stretch of the Mississippi River from New Orleans to Baton Rouge, Louisiana, an area commonly referred to as "Cancer Alley." Or one might find communities ringed by industrial facilities and landfills, such as Chicago's far South Side, ${ }^{10}$ or the communities nestled among the oil refineries of the Gulf Coast region. " Tribal governments are often solicited by the U.S. government and other private developers for the use of tribal lands for the placement of mining, nuclear waste facilities, and other intensive polluting energy projects. ${ }^{12}$

But proximity to risk-producing land uses, or siting controversies involving new or expanded facilities, are not the only environmental justice issues that activists have addressed in the last 15 to 20 years. They have also uncovered and examined race and class disparities in a wide

tion of the initial siting challenges and a history of the environmental justice movement.

8. Id.

9. This is an area between Baton Rogue and New Orleans. Marianne Lavelle, Saying "No" to Cancer Alley, in Marianne Lavelle et al., Unequal Protection: The Racial Divide in Environmental Law, NAT'L L.J., Sept. 21, 1992, at S1-S12, S5 (a special investigation).

10. Marianne Lavelle, Community Profile: Chicago, An Industrial Legacy, in Lavelle et al., supra note 9, at S3.

11. See, e.g., Environmental Integrty Project, Accidents Will Happen: Pollution From Plant Malfunctions, Startups, and ShutDOwns In POrt Arthur, Texas (2002), available at http://www.rffund. org/eip/docs/ReportOnUpsets.pdf (last visited May 11, 2003); ENVIRONMENTAL INTEgrty ProJect, SMoKIng Guns, SMOKINg Flares, AND UNCOUNTED Emissions From Refineries and Chemical Plants in Port Arthur, Texas (2002), available at http://www.fffund.org/eip/docs/SmokingGuns. pdf (last visited May 11, 2003); Eileen Gauna, Fairness in Environmental Protection, 31 ELR 10528, 10554-57 (May 2001) (discussing proposal to allow refineries to obtain expedited permits and other favorable regulatory treatment).

12. See generally Indigenous Environmental Network website, at http://www. ienearth.org (last visited May 11, 2003). 
range of agency activities carried out by federal and sub-federal agencies. For example, environmental justice advocates have challenged the U.S. Environmental Protection Agency (EPA) for the way that policy is developed and implemented, programs designed, standards set, facilities permitted, laws enforced, and contaminated sites cleaned up. ${ }^{13}$ They have challenged transportation policies, ${ }^{14}$ examined beach access, ${ }^{15}$ and contested the placement of parks and green spaces. ${ }^{16}$ Activists have also addressed a myriad of process issues as well. In the course of addressing environmental issues, they have often found themselves cut off from effective participation by a variety of obstacles. ${ }^{17}$ Sometimes, it has been due to the hostility of other stakeholders and governmental officials. ${ }^{18}$ Other times, it has been due to lack of time, resources, and technical experts. But there are more subtle impediments to effective participation and advocacy. The way that decisionmaking structures are designed, and the biases embedded in them, often serve to assume away, trivialize, or eclipse environmental justice issues. ${ }^{19}$ Thus, analyzing these power structures and decisionmaking processes, and devising strategies for negotiating the unequal playing field of environmental protection, land use, and water law, is "bread and butter" environmental justice work. By virtue of their intimate connection to the land and their economic vulnerability, environmental justice communities fully appreciate, perhaps better than most stakeholders, that the issues cannot be reduced to simplistic jobs or environment choices. The

13. Eileen Gauna, An Essay on Environmental Justice: The Past, the Present, and Back to the Future, 42 NAT. Resources J. 701, 705 (2002).

14. See Environmental Justice Resource Center, Transportation Equity, at http://www.ejrc.cau.edu/transequnews.htm (last visited May 11, 2003).

15. Marc R. Poirier, Environmental Justice and the Beach Access Movements of the 1970s in Connecticut and New Jersey: Stories of Property and Civil Rights, 28 ConN. L. Rev. 719 (1996).

16. Samara F. Swanston, Environmental Justice and Environmental Quality Benefits the Oldest, Most Pernicious Struggle and Hope for Burdened Communities, 23 VT. L. REv. 545 (1999).

17. See generally Eileen Gauna, The Environmental Justice Misfit: Public Participation and the Paradigm Paradox, 17 STAN. ENVTL. L.J. 1 (1998).

18. An interesting account of this hostility can be found in Luke W. Cole, The Struggle of Kettleman City: Lessons for the Movement, $5 \mathrm{MD}$. J. CoNTEMP. LEGAL IssUES 67 (1993/1994) (describing a permit hearing for an incinerator in Kettleman City, California).

19. For a description of this dynamic in the permitting process, see RECHTSCHAFFEN \& GAUNA, supra note 7, at 187-215 and Gauna, supra note 11. 
issues that environmental justice activists and advocates address are diverse, complex, and persistent.

Some of those issues involve water; in particular, water allocation, pollution, and the associated land uses that affect water quantity and quality. More often than not, in the environmental justice context these disputes involve fundamentally different values, cultures, and ways of perceiving this precious natural resource. Some examples follow.

\section{A. Water Flow and Availability}

A river's natural hydrological cycle, or flow regime, includes periodic flooding and other "keystone" processes. ${ }^{20}$ In order for a river to remain healthy and alive, some conservationists argue that dams, drains, and diversions should attempt to mimic the natural hydrograph of the river. For example, one conservationist proposes the creation of a levy system that allows the natural overbank spring flows to promote regeneration of cottonwoods, speed decomposition and recycling of nutrients, or carry off or dampen understory fuels. ${ }^{21}$ To preserve endangered species, there is also the need to keep flows higher than might otherwise occur under allocations and diversions presently allowed under the existing water rights regime. These are but a few examples of the changing state of conventional wisdom. In place of the aggressive plumbing projects of the empire builders of past generations, the idea now is to keep rivers in their natural state and leave as much water in them as possible. Both of these ideas find support in Dryland Democracy and Professor Neuman's discussion of Powell's vision of a sustainable West. In the abstract, this sounds like an ecologically sound idea, but to do so under the West's existing system of water rights will put intense pressures on current water users. The fundamental question remains: which users are likely to be the most vulnerable to increased scarcity in the amount of water available for diversion and consumptive uses?

One of the losers in this ecological project might be the acequia communities of northern New Mexico and southern Colorado, communities that are already struggling to maintain a traditional vision of shared water use, which is at odds with the current law of prior appropriation. The case of the acequias in Colorado's Rio Culebra Watershed provides a good example of these vulnerabilities. In this discussion I draw largely

20. William deBuys, Navigating the River of Our Future: The Rio PocoGrande, 41 NaT. Resources J. 265, 270 (2001).

21. William deBuys was speaking of the Middle Rio Grande District in New Mexico. Id. at 275. 
upon the work of anthropology professor Devon Peña and law professor Gregory Hicks. Professors Peña and Hicks, in a recent work, carefully map out the history and the social and legal complexities of the acequia communities of southern Colorado. ${ }^{22}$ I also draw heavily from the work of David Benavidez, an attorney who works closely with acequia communities in northern New Mexico. ${ }^{23}$

Other than Native American tribal governments, acequia communal arrangements are among the oldest local governmental institutions in the United States. ${ }^{24}$ They are centered around a system of building and maintaining intricate, gravity-fed ditch irrigation systems that rely heavily upon knowledge of local topography and environmental conditions and farming techniques that are passed from generation to generation. The acequias are not simply irrigation and farming technology, but stable cultural practices, norms that gave rise to a strong sense of community identity. ${ }^{25}$ Hicks and Peña have identified five major princi-

22. Gregory A. Hicks \& Devon G. Peña, Community Acequias in Colorado's Rio Culebra Watershed: A Customary Commons in the Domain of Prior Appropriation, 74 Colo. L. Rev. 101 (2003).

23. David Benavidez, The Social Costs of Moving Water in Northern New Mexico (unpublished manuscript) (manuscript on file with author).

24. Hicks \& Peña, supra note 22, at 155.

25. Hicks and Peña explain:

Intense social relationships on the acequia create a sense of what Gallegos calls the "acequiahood," the neighborhood of irrigators or the condition of a sense of place embodied by the affinities of belonging to the acequia institution. The sense of neighborliness is reinforced by the annual cycles of labor activity. This involves not just the spring ditch cleanup but a wide range of other activities related to irrigating, planting, cultivating, harvesting, and processing of crops. The circumstances of limited economic resources means the acequia farmers must rely on mutual aid strategies to survive. Thus, it is common for acequia farmers to share resources including labor, farm tractors, plows, cultivators, combines, and other implements, seed, and even land.

The traditions of mutual aid and cooperative labor are evident in the organization and objectives of the [Colorado acequia Association]. The Association's mission statement highlights this commitment to mutual aid and cooperative labor by declaring that the acequias are a "local grassroots participatory democracy." This participatory democracy extends to labor processes. It is common among the Culebra acequias for participantes to participate in the planting, cultivating, and harvesting of each other's crops. Elder farmers like Adelmo Kaber and Evan 
ples that dominate this governance: (1) individual usufructuary rights to a common pool resource that emphasizes the community instead of the commodity value of water; (2) the nontransferability of water; (3) the right of thirst; (4) the practice of cooperative labor or mutual aid; and (5) the principle of local self-governance. ${ }^{26}$ This form of self-governance has placed acequia communities at odds with a strict priority system of prior appropriation that was imposed under the U.S. legal system.

The ancient customary law of acequias finds its roots in Roman, Spanish, Arabic, and Pueblo Indian sources. ${ }^{27}$ It differs from current state laws in several ways. In times of scarcity, water is not viewed as private property but as a common resource to be allocated based upon principles of equity and necessity. ${ }^{28}$ Because water is viewed as intrinsic to the land, it is not sold for use outside the acequia system. So

Valdéz assist younger farmers with this work and in the process share their local knowledge of agroecology. For example, Adelmo Kaber often makes suggestions to younger farmers about the appropriate crops for a given soil type or recommends the least erosive techniques for plowing fields before planting. The reproduction of local agroecological knowledge is therefore completely dependent on the intimate social relations that characterize the interactions among elder and more youthful participantes.

The Association has over the years emphasized the importance of reproducing the next generation of acequia farmers. A concern for the needs of limited resource farmers extends to the provision of services for women and youth who are just starting to engage in agricultural work. One strategy has been to provide new farmers with support in acquiring heirloom seeds, gaining access to planting, cultivating, and harvesting equipment, and mentoring them in the arts of flood irrigation. The sharing of resources also involves an informal network of seed savers and exchangers. In fact, the practice of heirloom seed saving is one of the most significant cultural traditions among acequia farmers of the Culebra watershed. Heirloom seed saving represents a connection to past generations and is an important agroecological adaptation to place ....

Id. at 162-63 (citations omitted).

26. Id. at 160 .

27. Id. at 157. This presents a legal complication, as the acequia rights are customary, Pueblo and tribal rights evolve under federal law, and prior appropriation has evolved under various state laws that may differ in significant respects. See also Benavidez, supra note 23, at 2 (discussing the historical background of acequias).

28. Hicks \& Peña, supra note 22, at 113. 
strong is this norm that some communities (through individual rights holders) have even rejected lucrative offers to buy water rights in times of plenty. ${ }^{29}$ A complementary principle, the "right of thirst," holds that water is also for the benefit of the plants and animals of the acequia ecosystem, and because of that principle, acequia communities have resisted the Colorado State Engineer's request to line ditches with cement. ${ }^{30}$ Not only is the right of thirst more in line with current ecological thinking, the wild plants and animals that the banks of the acequias support are important sources of food or medicine for the acequia communities. ${ }^{31}$

Some states recognize the acequia system in limited respects. For example, New Mexico provides that the acequias themselves are tenancies in common, and acequias are political subdivisions of the state, but the water rights are privatized, a feature not recognized under prior sovereigns. ${ }^{32}$ To successfully operate within a regime of individual prop-

29. As Hicks and Peña note:

These customary principles are not abstractions or mere memories of a cultural heritage and political legacy that has long since past. Despite the imposition of the appropriative rights regime, these principles continue to guide the organization and management of contemporary community acequias throughout the Upper Rio Grande. For example, in 1989, a Houston-based multinational corporation, Battle Mountain Gold (BMG), offered the San Luis People's Ditch $\$ 50,000$ for temporary water during the construction of a gold mine and cyanide leach vat milling facility located in the Rito Seco Creek watershed about six miles northeast of the town of San Luis. The People's Ditch firmly rejected the offer on two separate occasions in years when plenty of water was available for all the acequias. As the former mayordomo of the San Luis People's Ditch explained, "You cannot sell the water and separate it from the land. The water belongs to the community. It is not for sale."

Instead of selling BMG water, the San Luis People's Ditch and other local acequias filed a lawsuit against BMG opposing the corporation's plans to transfer agricultural water rights to industrial uses. This incident illustrates how the riparian and community value of water remain fundamental principles guiding the management of acequia water rights in the Culebra watershed.

Id. at 161-62.

30. Id.

31. Id.

32. Benavidez, supra note 23 , at 3 . 
erty rights, acequia communities have collectively found ways around the legal results of prior appropriation. For example:

The 2002 drought was so severe that only three of the twenty-three acequias were apportioned water sufficient for irrigation. Many of the farmers were thus left high and dry. Where circumstances permitted, farmers from dry acequias planted on extra acreage on land belonging to farmers with running acequias. For example, Adelmo Kaber, a farmer on the Cerro Ditch without water for the 2002 irrigation season, planted chicos, beans, calabasa and other crops on several acres belonging to Joseph C. Gallegos, who was able to irrigate with water from the San Luis People's Ditch.

In this manner, the acequia farmers of the Culebra watershed manage to find new ways to share scarcity. Because the extant legal regime of prior appropriation does not allow for the sharing of water scarcity, the farmers cooperate by growing food together on the limited land that can be irrigated. Of course, while these adaptive responses to water scarcity are laudable, they do not eliminate the economic hardship that results wherever ditches run dry under the restrictive demands of priority calls for limited water. The principle of the right of thirst is abrogated, and participantes (participants in the system) are prevented from managing their water resources on the basis of collective goals of the community. ${ }^{33}$

Careful not to romanticize, the authors note that this arrangement is compelled by strict necessity. Everyone in the acequia system, from the mayordomo (ditch boss), to the comisionados (commissioners), to the participantes understand that the whole system depends upon feasance to these norms. The maintenance of the irrigation system depends upon shared labor and values. Thus, even the most senior rights holders are not individually secure under a system of strict prior appropriation. ${ }^{34}$

33. Hicks \& Peña, supra note 22 , at $166-67$.

34. Hicks and Peña explain:

[T] he very holders of senior water rights, who benefited from the priority established by Colorado water law, believed that their own interests would be jeopardized if the holders of junior rights were forced to sell their land and water rights because of continuing scarcity. The possible shift of water away from acequia-dependent uses threatened the end of the acequias as a water delivery system and as a political, economic, and social institution vital to the cohesion of the community.

A new generation of uses that neither depended upon the acequia system nor provided usable retum flows to the acequias would reduce the total volume of water carried through the acequias, frustrating the ability of the earthen ditch 
The acequia communities, having survived for generations under a foreign legal regime, are nonetheless endangered today. They are threatened by the press of a globalized economy where large multinational corporations increasingly dominate economic activity with water-intensive industries, ${ }^{35}$ increasing pressure to sell water rights, ${ }^{36}$ the influx of new landowners into the system that do not adhere to the communal norms, and multiplying residential developments in the area. A case from New Mexico is illustrative.

In Wilson v. Denver, ${ }^{37}$ the New Mexico Supreme Court addressed the issue of whether an election of a mayordomo and the comisionados was legal by a one vote per landowner arrangement, as is customary, or whether the vote should have been in proportion to water rights shares per hour. The facts of the case demonstrate the vulnerability of this ancient system. The dispute arose when the Wilson family, headed by Dr. John N. Wilson, who owned a 750-acre ranch upstream from 20 acequia households, piled manure from their Norwegian fjord houses too close to the acequia. The downstream landowners were concerned about damage to the acequia system and potential contamination of domestic water wells. The local acequia association offered to help build a new fence to keep the horses away from the acequia. The Wilson family refused their offer, considering such an attempt an interference with their property rights. During the 1994 and 1995 elections of the mayordomo and comisionados, the Wilsons asserted that their vote should count in proportion to their shares, which would have given

networks to operate. Another basis of concern was that the community of labor that has maintained the ditch system at relatively low cost would be undermined if land in the watershed were separated from the acequia system. Neighbors would no longer look to each other to keep the system up. At a certain point there would be too few owners to maintain the acequia system, and those who remained would lack the resources to purchase services to replace the many acts of mutual aid and forbearance that define the acequia neighborhood and allow it to function. The successor system, and the successor landscape, would, it was feared, be inferior with respect to functionality and to amenity.

Id. at 154-55.

35. See discussion of the Intel case, infra note 41 and accompanying text.

36. See discussion of the offer to purchase water rights by BMG, supra note 29.

37. 961 P.2d 153, 156-57 (N.M. 1998). For a discussion of this case, see Cristopher J. DeLara, Who Controls New Mexico's Acequias? Acequia Government and Wilson v. Denver, 40 NAt. ResourCES J. 727 (2000). 
them $61 \%$ of the vote. Using their proportional vote would have allowed the family to place John and Barbara Wilson into commissioner positions and Nat Wilson as mayordomo. The acequia community refused, instead holding the election in a customary one vote per landowner manner. The New Mexico Supreme Court upheld the one vote per landowner election results, but the facts of the case illustrate how an acequia community, dependent upon voluntary compliance with communal norms, is vulnerable to existing laws and institutions that may not be as accommodating to the traditional forms of acequia governance.

Another vulnerability is the legal ability of individual water rights holders to sever the water rights from the acequias. This potential exists because in the last three decades the Southwest has experienced much wetter conditions than average. Thus, what is commonly thought to be "drought conditions" in the last few years is in fact a return to the longterm average rainfall. ${ }^{38}$ This return to normal aridity may result in priority calls over several years. Junior rights holders might not be able to survive the scarcity over a prolonged period, even with informal landsharing arrangements with senior rights holders. If they sell their land and water rights to individuals or corporations that reject the norms of the acequia system, these new landowners are more likely to transfer water rights outside of the ditch system, leaving the remaining participants in the legally untenable position of having to challenge the transfers. ${ }^{39}$

Many of the landowners in acequia communities are Latino families that have few resources and economic options - other than land that has remained in their families for generations - and as such, the demise of the system will have a racially disparate impact. The viability and autonomy of these communities is an environmental justice issue. ${ }^{40}$ Whether these endangered communities will fare better under a water basin institution with consolidated authority from federal and state law regimes is a matter that may be far too speculative to allow for much comfort.

Groundwater pumping is another issue that raises environmental justice concerns. Because there is comparatively little surface water, population growth in parts of the Southwest has been supported by

38. BELIN ET AL., supra note 2, at 4.

39. See Sleeper v. Reynolds, 760 P.2d 787 (N.M. Ct. App. 1988).

40. See Devon G. Peña, Lecture: Autonomy, Equity, and Environmental Justice, Provost's Lecture Series on Race, Poverty, and Environmental Justice, Brown University (Apr. 21, 2003) (manuscript on file with author). 
groundwater. This trend has threatened the viability of the aquifers and, by hydrological connection, the water basins. It also pits agricultural rural communities against cities and incoming industries. Again, another case out of New Mexico is illustrative. In the early 1990s, the Intel Corporation applied to the New Mexico State Engineer to acquire a permit to pump 4,500 acre-feet per year (1.5 billion gallons per year) of groundwater to expand its facility near the village of Corrales. ${ }^{41}$ The residents of Corrales were concerned about a variety of issues, ${ }^{42}$ but a chief concern was that their domestic water wells would be affected by Intel's use of so much water. ${ }^{43}$ Many of the estimated 2,728 domestic wells were located near the Intel well site. The Corrales residents anticipated that many of these wells would require additional drilling or submersible pumps. ${ }^{44}$ Intel made the usual economic arguments, asserting that the expansion would result in additional jobs and indirect benefits from increased economic activity. ${ }^{45}$ The State Engineer allowed the permit despite his prediction that some domestic wells in the area would need to be redrilled or deepened. He did not directly apply New Mexico's "public welfare" criterion ${ }^{46}$ to the transfer and instead noted that decisions regarding growth and economic development are better deter-

41. This case is discussed at length in a student note. See Susanne Hoffman-Dooley, Determining What Is in the Public Welfare in Water Appropriations and Transfers: The Intel Example, 36 NAT. RESOURCES J. 103 (1996).

42. As in many environmental justice disputes involving facility siting or expansions, there were a range of concerns. The residents were also concerned about air quality, waste disposal, increased traffic, and indirect subsidies through tax abatement, which were estimated at about $\$ 250,000$ in abatements per job created. Id. at 117 . For this and other examples of high tech industry subsidies and their effect on water resources, see SoUTHWEST Organizing Project, Intel Inside New Mexico: A Case Study of ENVIRONMENTAL AND ECONOMIC INJUSTICE (1994) [hereinafter INTEL INSide New MeXico]; Southwest Network for ENVIRONMENTAL AND Economic Justice and Campaign for Responsible Technology, SaCred Waters: Life Blood of Mother Earth, Four Case Studies of High-Tech Water Resource Exploitation and Corporate Welfare IN THE SOUTHWEST (1997).

43. Hoffman-Dooley, supra note 41 , at 115.

44. Id. at 116.

45. Id. at 117.

46. The public welfare criterion is a requirement that before approving a water transfer or diversion, the state engineer should determine that the water transfer should be in the public welfare. 
mined through local zoning and land development authority. ${ }^{47}$ This example evidences the fairly typical tendency of regulatory agencies that deal largely with scientific and engineering issues to avoid socioeconomic factors. ${ }^{48}$ With regulators' inclination to avoid socioeconomic issues, the more powerful interests with greater resources to purchase water rights will inevitably prevail, notwithstanding the serious social costs that may ensue.

\section{B. Water Quality}

There are also serious water quality issues facing environmental justice communities in the Southwest. In general, water pollution is direct and obvious, such as contaminated runoff, facility effluent, and deposition of air pollutants into surface waters. But there are less obvious reasons why water pollution affects people of color, native populations, and the poor more than the general public. The key to this fact lies in the way that the Clean Water Act (CWA) is administered. ${ }^{49}$ Under this Act, point sources (factories, for example) must acquire a permit before discharging pollutants into a body of water. There is very little in the way of mandatory requirements for nonpoint sources, e.g., agricultural practices that result in pesticide and fertilizer runoff. The point sources are required to use technology-based standards to control the pollutants in their discharged effluent. As the term suggests, these standards are based upon control technology currently available, and when combined with similar dischargers and nonpoint runoff on the same water body, the water can be severely polluted despite the fact that none of the pollutants are entering the river or lake illegally. In an attempt to avoid or correct this situation, the CWA requires states to designate the uses for each body of water and adopt water quality standards for the designated use. For example, a "fishable-swimmable" designated use requires water quality adequate to support those uses, i.e., that pollutant levels will be low enough so that the fish caught and consumed will be safe to eat. If the water body does not meet the water quality standards for various

47. Id. at 119 (citing In re the Applications of Intel Corporation to Appropriate the Underground Waters of the State of New Mexico in the Rio Grande Underground Water Basin, Nos. RG-57125 et al. (June 10, 1994)).

48. Gauna, supra note 17, at 35-36.

49. For a good overview of the CWA, Pub. L. No. 92-500, 33 U.S.C. $\S \S 1251-1387$, ELR STAT. FWPCA $\S \S 101-607$, and its administration, see Robert V. Percival et al., Environmental Regulation: Law, SciENCE, AND Policy 569-699 (4th ed. 2003). 
types of pollutants, additional planning and control measures are supposed to be put into place.

However, the environmental justice concerns arise in the process of developing water quality standards that will determine whether the water is clean enough to support a healthy fish population in the first instance. EPA develops water quality guidelines that the states may adopt. This endeavor requires an assumption about how much fish people typically eat. Initially, EPA assumed that the average person consumed about 6.5 grams per day of fish caught in the same water body over a 70-year period, approximately one eight-ounce serving per month. In the fall of 2000 , due in large part to pressure from environmental justice advocates, EPA revised its criteria to 17.5 grams per day for the general population and recreational fishers, and 142.4 grams per day for subsistence fishers. ${ }^{50}$ However, many federal and state water quality standards currently in effect are still based upon the old 6.5 grams per day standard. The reason this is such an important environmental justice issue is explained in a recent report by the National Environmental Justice Advisory Council to the EPA Administrator:

The contamination of fish, aquatic plants, and wildlife is an especially pressing concern for many communities of color, low-income communities, tribes, and other indigenous peoples, whose consumption and use practices differ - often profoundly so-from those of the general population. Members of these groups often consume far greater quantities of fish, aquatic plants and wildlife; they consume fish, plants and wildlife at different frequencies, in accordance with seasonal availability and other cultural considerations; they consume and use different species and parts; and they employ different methods in procuring and preparing the fish, aquatic plants and wildlife that they use. Thus, communities of color, low-income communities, tribes and other indigenous peoples are among the most highly exposed to contaminants in the fish, plants, wildlife, and aquatic environment. For example, empirical studies document 90 th percentile fish consumption rates for various affected communities and tribes at 225 [grams per day (g/day)], $242 \mathrm{~g} /$ day and $489 \mathrm{~g} /$ day (respectively, urban fishers on Los Angeles Harbor, Cal.; Asian and Pacific Islander communities

50. National Environmental Justice Advisory Council, Fish Consumption and EnVironmental Justice, A Report Developed From the National Environmental Justice Advisory Council Meeting OF DeCEMber 3-6, 2001, at 30 (Nov. 2002 and Addendum dated Dec. 2002), available at http://www.epa.gov/compliance/resources/publications/ej/fish_ consump_report_1102.pdf (last visited May 11, 2003). 
in King County, Wash.; and the Suquamish Tribe). Although EPA's revised default assumptions of $17.5 \mathrm{~g} /$ day, representing the 90 th percentile of the general population, and $142.4 \mathrm{~g} /$ day, representing the 99th percentile of the general population are a marked improvement over its previous assumption of $6.5 \mathrm{~g} / \mathrm{day}$, the revised defaults still considerably underestimate exposure for many affected communities and tribes. ${ }^{51}$

Clearly, a water basin institution with a mission to preserve the integrity of the basin ecosystem must address the issue of water quality standards, point and nonpoint pollution. A consolidation of authority only over water allocation and land use laws would not be sufficient; the basin institution would have to have delegated federal authority under environmental laws, for example authority to adopt water quality standards.

Another major problem with achieving even existing (insufficiently protective) standards is that pesticide and fertilizer runoff, as well as other nonpoint pollution, has continued virtually unregulated under the CWA. Within the last few years, there has been increased regulatory activity around a planning provision that requires states to come up with total maximum daily load (TMDL) plans for water quality limited waters. $^{52}$ These plans are supposed to bring in nonpoint source pollution control as well. However, as explained by Prof. Oliver Houck, this kind of ambient-based regulation is hampered by the limited state of science and the substantially limited state of political will. ${ }^{53}$ If states were to delegate TMDL planning and implementation authority to a water basin institution (assuming it were legal to do so), the institution would encounter the same difficulties and the same powerful interest groups that have resisted TMDL planning. And the basin institutions would have to devise a way to increase the capacity for meaningful participation of environmental justice communities within this planning process, a feat that has yet to be accomplished under current regulation. Another particularly difficult task for a basin institution will be controlling air pollution, particularly the deposition of mercury, which comes largely from power plants. Mercury, and other toxins that bioaccumulate in the fatty tissues of fish, is very harmful. Under current law, mercury air emissions air controlled by technology-based standards based upon

51. Id. at 3-4 of Addendum.

52. Oliver A. Houck, TMDLs IV: The Final Frontier, 29 ELR 10469 (Aug. 1999).

53. Id. 
maximum achievable control technology ((MACT) standards), but the Bush Administration is vigorously promoting a "Clear Skies Initiative" in the form of proposed legislation that will allow power plants to trade emission allowances and will delay mercury controls required under current law. Depending upon how these types of trading regimes are designed - and they are often designed to provide maximum flexibility for facility operators - then "hot spots" can occur when a large facility or group of facilities decides to buy emission allowances rather than install stringent pollution control. It might be exceedingly difficult, if not impossible, for a water basin institution to control deposition of air borne mercury into water bodies under this type of regime.

One might reason that a water basin institution, with land use authority within the basin ecosystem, would be able to better exercise control over new facility siting and facility expansions and would do so with an eye toward protecting the river or lake and, indirectly, the populations that rely upon that water body. But under the current system, these emission- and effluent-increasing activities continue to take the path of least resistance and end up in indigenous, low-income, and people of color communities. ${ }^{54}$ More so, perhaps, in the demographically changing arid West. Recent studies from the Los Angeles area strongly suggest that the statistical community of choice for siting unwanted land uses is a community undergoing an ethnic shift from one community of color to another. The authors of this study posit that social ties are weakened when a community is experiencing a population transition; therefore, these communities are even less able to organize and challenge a facility siting or expansion. ${ }^{55}$ Add to these land use problems the limited

54. In two studies, Prof. James Hamilton has looked at how capacity decisions of hazardous waste facilities correlate with the demographics of host communities. In the first, using data at the county level, Professor Hamilton found that race and income were not significant factors in expansion decisions by facilities from 1987 to 1992, but that race was a significant determinant of the facilities' plans to reduce capacity of waste facilities (facilities in white communities were more likely to reduce capacity than facilities in communities of color). Hamilton also found that both race and income were significant predictors of where hazardous waste facilities were sited in the 1970s and early 1980s. James T. Hamilton, Politics and Social Costs: Estimating the Impact of Collective Action on Hazardous Waste Facilities, 24 RAND J. ECON. 101 (1993).

55. Manuel Pastor Jr. et al., Which Came First? Toxic Facilities, Minority Move-in, and Environmental Justice, 23 J. URB. AfF. 1 (2001). Nicholas Targ, Counsel to the EPA Office of Environmental Justice, has written a law review article on the related "social capital" theory. Nicholas Targ, Three 
options that people of color have due to the legacy of expulsive zoning, ${ }^{56}$ the unfortunate reality that low-income and people of color communities are often the buffers between risk producing land uses and more wealthy residential areas, and other intensive zoning practices. ${ }^{57}$ The result is that a basin institution willing to accept plenary authority will have challenges that do not rest exclusively with water flow, availability, and quality. Sound policy necessitates a broader mission to control and correct indirect but significant social costs.

\section{The Clash of Values}

The scenarios described above illustrate that, in environmental justice issues, what are at stake are not just competing economic uses of water, but important noneconomic values as well. Native American tribes are willing to go to great lengths to preserve their sovereignty. Tribal sovereignty aside, sacred sites and certain uses of water are intrinsic to their land-based religions. ${ }^{58}$ Acequia communities are fiercely protective of cultural traditions tied to the communal ditch system. These interests cannot be balanced easily against the interests of powerful economic actors.

Officials within a basin institution will have to be mindful that the aggregate of water allocation, land use, and pollution control decisions can result in racially disparate distributions of burdens and benefits. Individual decisions can exacerbate existing racial disparities. The design of the decisionmaking structure of the institution can further erode prin-

Paths to the Environmental Justice Goal: Social Capital, Going Beyond Meaningful Public Participation (unpublished manuscript) (draft on file with author and available from Nicholas Targ). See also Nicholas Targ, A Third Policy Avenue to Address Environmental Justice: Civil Rights and Environmental Quality and the Relevance of Social Capital Policy, 16 Tul. ENvTL. L.J. 167 (2002). A study at the zip code level found that after controlling for other demographic variables, race was not a significant variable in explaining facility capacity expansion, but that the potential for collective action (as measured primarily by voter turnout) was a significant variable. James $\mathrm{T}$. Hamilton, Testing for Environmental Racism: Prejudice, Profits, Political Power?, 14 J. Pol'y ANalysis \& Mgmt. 107, 121-27 (1995).

56. Yale Rabin, Expulsive Zoning: The Inequitable Legacy of Euclid, in ZoNING and THE American Dream 101 (Charles M. Haar \& Jerold S. Kayden eds., 1989).

57. See Craig Anthony (Tony) Arnold, Planning Milagros: Environmental Justice and Land Use Regulation, 76 Denv. U. L. REv. 1 (1998).

58. See infra Part III. 
ciples of sovereignty of Native American tribal governments. These values will be certain to compete with the economic interests of major water users such as large-scale agriculture, industry, and municipalities. To add to the complexity of the situation, racially disparate results and damage to religious practices implicate principles embedded in the U.S. Constitution and civil rights laws.

In light of these considerations, these issues cannot, and should not, be resolved solely by resort to markets and the principle of economic efficiency, which is premised upon a willingness-to-pay criterion. Yet, just as existing institutions confront the growing demand by powerful interest groups to promote and facilitate trading in water rights and pollution credits, a basin institution will be subject to the same pressures. Wealthier stakeholders, such as the major water users and industry moving to the arid West, are the primary beneficiaries of such a system.

Even assuming that water transfers and tradeable pollution credits are more strictly controlled than market proponents envision, there are still inherent difficulties in balancing economic interests against noneconomic interests under the current regulatory regime. For example, Prof. Tseming Yang notes that civil rights claims have fared badly in the environmental regulatory context precisely because environmental law is largely an interest balancing process, whereas the nature of adjudication and discourse under civil rights laws are premised upon a paradigm of maximizing the rights of minorities who have historically been subject to discrimination. ${ }^{59}$ The policy underlying pollution control laws, in particular, accepts pollution as a necessary consequence of our standard of living and, within that context, does not easily allow for a more narrow focus of protection of one group of stakeholders. ${ }^{60}$ Whether a basin institution will be able to protect aquatic ecosystems, while at the same time protecting the autonomy and community of the poor and people of color who might be operating under a different set of values, will depend upon its design and implementation. Basin institutions that are no more than vessels of consolidated authority will not suffice. Something more is necessary.

59. Tseming Yang, Balancing Interests and Maximizing Rights in Environmental Justice, 23 Vr. L. REv. 529, 529-30, 534 (1999).

60. Id. at 534-35. 


\section{Environmental Justice Under a Water Basin Institution}

\section{A. Consolidating Authority}

Before discussing how environmental justice concerns might fare under a basin management approach, it is important to anticipate the process of consolidating authority. To be sure, an agency's penchant for turfguarding will be the biggest political obstacle. And Professor Neuman is correct in pointing out that agency power so jealously guarded is illusory to begin with, considering that it ultimately ends up simply as the power to guard power, or defend decisions, in protracted court proceedings. But there is a special consideration in what might otherwise appear to be a dysfunctional tendency of governmental institutions. That consideration concerns the sovereignty of Native American tribes. Tribal sovereignty has been steadily under attack for decades, and every legal challenge to this sovereignty brings increasing concern for tribal governments. ${ }^{61}$ State and tribal governments along large rivers are actively involved in disputes and acrimonious litigation with each other. Tribes might be understandably hesitant to give up guarded tribal authority to basin management institutions with no experience, and no track record, of addressing intersovereign disputes. Moreover, this is not the run-ofthe-mill conflict between and among different levels of government. As explained by Prof. Rebecca Tsosie, at issue is tribal self-determination that is indispensable to protecting very specific sets of values that differ from mainstream westem values. ${ }^{62}$ A case involving water quality standards and the Isleta Pueblo provides an example.

In City of Albuquerque v. Browner, ${ }^{63}$ the Isleta Pueblo promulgated a set of comparatively stringent water quality standards that would pro-

61. The most recent high profile case is Inyo County v. Paiute-Shoshone Indians of the Bishop Community of the Bishop Colony, cert. granted, 123 S. Ct. 618 (2002), vacated, 123 S. Ct. 1887 (2003) (holding that a tribe is a not a "person" for purposes of 42 U.S.C. $\$ 1983)$. One of the questions presented by the petitioners was whether the doctrine of tribal sovereign immunity enables Indian tribes, their gambling casinos, and other commercial businesses to prohibit the searching of their property by law enforcement offices for criminal evidence pertaining to the commission of off-reservation state crimes when the search is pursuant to a search warrant issued upon probable cause.

62. Rebecca Tsosie, Tribal Environmental Policy in an Era of Self-Determination: The Role of Ethics, Economics, and Traditional Ecological Knowledge, 21 VT. L. REv. 225, 226-27 (1996).

63. 97 F.3d 415, 27 ELR 20283 (10th Cir. 1996). 
tect the tribe's use of the Rio Grande for ceremonial purposes. The upstream city of Albuquerque protested, in large part because discharges allowed under a water treatment facility's national pollutant discharge elimination system permit would cause a violation of the water quality standards in the downstream segment used by the tribe. Ultimately the U.S. Court of Appeals for the Tenth Circuit upheld EPA's approval of the tribe's water quality standards. One has to wonder how this case, not only involving different uses of the water resource but involving a conflict of fundamentally different cultural and religious values, would be resolved under the processes of a basinwide institution with consolidated authority spanning several states. One also has to wonder if Native American tribes will be amenable to giving up the protection of hard-fought legal victories upon a blind faith in a newly created water-basin institution with a larger set of stakeholders. As such, the consolidation process itself must have substantial participation by tribal governments, and there would have to be concrete assurances that noneconomic cultural values will be preserved by the basin institution and that U.S. trust responsibility is fully recognized and implemented.

\section{B. Potential Benefits}

Assuming such assurances are made, that federal, state, and local law is changed to allow for the creation of basinwide institutions with expansive consolidated authority, and that sufficient resources are allocated toward that end, one can easily imagine the potential benefits of such a regulatory regime. A basinwide institution that has sufficient authority over water allocation, including groundwater pumping and agriculwural, industrial, and other land use practices, is much better positioned to address cross-media problems. In fact, a water body is perhaps the best "indicator media." Just as the presence and plentitude of certain species are indicative of the overall health of an ecosystem, such as an old growth forest, the health of a water body is similarly indicative of the overall health of the regional land ecosystem as well. A free-flowing water body that can support healthy native aquatic species can be accomplished only by controlling soil and groundwater contamination, fertilizer and pesticide runoff, deposition of air pollutants, sediment from construction, and runoff of pollutants from asphalt and other impervious surfaces. In this respect, basin institutions have the potential to serve the broader purpose of addressing crossmedia pollution problems. 
The more direct environmental justice benefits are equally attractive. Populations that rely on subsistence fishing will not have to continue to suppress their historical intake of protein due to frequent fish advisories. A basinwide approach seems better equipped to prevent toxic hot spots caused by too many point source discharges in one area and is better equipped to address the cumulative pollutant load from multiple source contributors, including nonpoint sources.

There are additional advantages to a basin institution with authority over land use matters. It will be better positioned to curb subsidies that not only result in inappropriate highly intensive water use, as described by Professor Neuman, but it can curb subsidies that result in additional pollution. A good example of this can also be found in New Mexico, where the issuance of an industrial revenue bond for the Intel facility was questioned on the grounds that the facility would use an enormous amount of water and emit highly toxic chemicals as well. ${ }^{64}$ As a result, curbing subsidies for plumbing, intensive water uses, and less direct subsidies that potentially impair water quality ultimately will result in abundant free flowing clean water throughout the basin.

\section{Potential Pitfalls}

As appealing as this idea is from an ecological perspective, however, there might be hidden distributional problems and social costs. If there is more water left in the river system to support adequate flow for a robust system, then there will be less water for residential, agricultural, commercial, and industrial uses associated with any given river system. The risk of a priority call under prior appropriation law will be more likely, or at least it might be perceived to be more likely. ${ }^{65}$ One has to contemplate what this new economic dynamic might mean for water right holders in more poor areas, where the residents own land but have little money or economic development. Will this result in displacement of modest but stable communities? Could this in turn have a racially disproportionate effect on people of color throughout the Southwest? It seems unlikely that a water basin institution-even if well run and undeniably devoted to the public interest-would be able to ward off some of the effects of the inevitable water scarcity that an ecosystem approach would generate. These inequities are likely to become more

64. INTEl INSIDE NEW MEXICO, supra note 42, at 12-19, 56-60.

65. BELIN ET AL., supra note 2. 
acute as public trust and public welfare standards are replaced by private markets. ${ }^{66}$

Aside from the economic questions, there are fundamental questions of process and how the water basin institution will govern and resolve competing interests. In Dryland Democracy, Professor Neuman suggests that this management approach might be more amenable to place-based decisionmaking. However, there are obvious difficulties accomplishing this in large river systems that span several states and contain numerous tributaries. Once water law, land use, and environmental regulatory authority are consolidated, very powerful vested stakeholder interests will become actively engaged in the inevitable tug of war over implementation policy and the interpretation of the statutes and regulations involved. In addition to the usual private stakeholders, there will be another group of powerful stakeholders - the very agencies that ceded authority to the water basin institution to begin with. Particularly when the basin institution is involved in planning and rulemaking, the stakeholders most likely to participate are those with significant regulatory interests and economic stakes, such as the major water users. Non-major water users and parties that may be indirectly impacted by water decisions do not participate in the current system, ${ }^{67}$ and there is little to suggest that would change. Lack of participation is not necessarily due to lack of interest, but rather lack of time and technical resources. ${ }^{68}$ One way to avoid this unfortunate result is for the water basin institution to play an active role in building the capacity of environmental justice communities to participate in the process. However, agencies typically profess a studious philosophy of neutrality toward stakeholders. Understandably, these governmental institutions do not like to be accused of preferring one set of stakeholders over others. While adherence to a such policy may be admirable in the abstract, hands-off neutrality ultimately allows regulatory processes to be dominated by well-financed interest groups. Since we are already in the realm of radical alternatives, a basin institution would do well to reject the "neutral umpire" proclivities of its predecessor agencies. Moreover, aggressively building participatory capacity can bring substantial benefits to the basin institution, especially along western river systems.

66. See supra notes 41-48 and accompanying text (discussing New Mexico State Engineer's decision on Intel application).

67. Consuelo Bokum, Implementing the Public Welfare Requirement in New Mexico's Water Code, 36 Nat. Resources J. 681,689 (1996).

68. Gauna, supra note 17. 
Some residents of rural communities bring with them a particular type of knowledge that is hard to come by, even by the bevy of biologists, ecologists, engineers, lawyers, and other experts that inhabit regulatory agencies. Long-time residents, by virtue of their intimate connection and dependency on the physical environment over long periods of time, understand the river.

How the water basin institution will design its processes to garner the greatest range of participation possible is an important question. Equally important, however, are the substantive principles and standards that will guide the use of its considerable discretionary authority. As illustrated above, some of the most difficult conflicts involve the clash between the economic needs of industrial, agricultural, and urban users, and the noneconomic needs of communities with land-based religions, such as the sacred sites and ritual uses of Native American tribes. Also at issue are uses that do not fit easily into either category, such as the interests of acequia communities that use the irrigation ditch system in part for subsistence crops, in part for crops that they sell, but whose use is tied to a strong cultural tradition that is indispensable to the identity and cohesion of very old communities struggling to survive in the 21 st century. While many state laws contain public welfare standards that can be used to provide some guidance, this standard may be undefined, poorly defined, or inconsistently defined by the various states within the basin institution's jurisdiction. ${ }^{69}$ Juxtapose this poorly defined concept with the inexorable march toward private markets in western water allocation and in pollution control, and one can easily predict the winners and the losers. Unless basin institutions are carefully designed under a different regulatory paradigm, regulation in a dryland democracy can very easily morph into a brutal zero-sum game.

\section{Some Exploratory Thoughts on "How To"}

Before the picture gets too bleak, there are encouraging signs of hope for the problematic scenario, that is, one involving vulnerable communities, severe environmental problems, fractured jurisdictional authorities, and powerful, entrenched special interests. The Interagency Workung Group on Environmental Justice, convened under former President William J. Clinton's Executive Order on Environmental Jus-

69. Bokum, supra note 7. See also Teresa McQueen, In the Matter of Howard Sleeper: A Debate Over Public Welfare and the Needs of a Diverse State, in Beyond Litigation: Case Studies in Water Rights Disputes 79-101 (Craig Anthony (Tony) Amold \& Leigh A. Jewell eds., Envtl. L. Inst. 2002). 
tice, ${ }^{70}$ sponsored a group of demonstration pilot projects. These projects might provide some insight into how, through the collaborative process, there is some hope for overcoming some of these difficult obstacles.

Many of the collaborative efforts were well underway before the Interagency Working Group formally adopted them as demonstration pilot projects. They typically involved a range of stakeholders, including an impacted community, private businesses, and local, state, and federal authorities. ${ }^{71}$ Some of them involved high-level elected officials, neighborhood associations, tribal governments, and migrant farmworkers. ${ }^{72}$ The typical mission involved addressing high pollution burdens in relatively small geographic areas. Many of the conditions in these areas had been left unaddressed for years, and frustrated communities often had an acrimonious relationship with various agencies and the private firms that were contributing to the high pollution burdens. Simply, political conditions were not ideal.

One particularly interesting project involves Barrio Logan, a low-income Latino community in San Diego that is beset by a range of private polluting entities, in addition to the nearby port and a military base that is exempt from some of the major environmental laws. ${ }^{73}$ Children's health, a value that cannot be easily weighed against economic interests, was of primary concern to the residents. The Environmental Health Coalition (EHC), a sophisticated environmental justice organization, had documented high exposure levels, high levels of asthma and other respiratory illnesses, cancer, and reproductive problems, and had debated the evidence with reluctant officials and private firms for years in other fora. As one EHC representative noted, they were skeptical and not interested in another failed "partnership" or a committee that would not get anything done. Nonetheless, they reluctantly joined the collaborative project and it has had moderate success, although not without having to overcome substantial obstacles. Not all major stakeholders participated. For example, U.S. Navy officials did not want to talk to non-Cabinet level officials and declined to join the project. This was a significant obstacle because the Navy repairs and changes out compo-

70. Exec. Order No. 12898, Federal Actions to Address Environmental Justice in Minority Populations and Low-Income Populations, 59 Fed. Reg. 7629 (Feb. 11, 1994), codified at 3 C.F.R. $\$ 859$ (1995).

71. For a sample of the projects, see ReChTSCHAFFEN \& GAUNA, supra note 7, at 404-09.

72. Id.

73. See id. at 411-14 for a description of this project. 
nents of its nuclear carriers in the area. ${ }^{74}$ There was ongoing, collateral litigation between some of the stakeholders. But the participants went forward despite these drawbacks.

Although the project is not a wild success, what is instructive is an analysis of the obstacles, and how they were overcome, by the various participants. At a forum convened by the Intemational City/County Management Association to examine collaborative models, the participants talked candidly about their experience in Barrio Logan. ${ }^{75}$ One factor identified as key to a successful collaboration was the presence of a sophisticated environmental justice organization with credibility in the community. There were other conditions that were also helpful, such as facilitation by persons knowledgeable about environmental justice issues. In addition, some participants had resources to commit to the project and the community was able to conduct an independent technical review of monitoring results and inventories of pollution sources. Participants in the Barrio Logan project agreed to set aside debates over evidence and focused on the goals of the collaborative effort. Lastly, state agency officials were careful to communicate to the communities what they could do and what they were not able to do for the community given various constraints on the agency. The EHC took agency personnel through "toxic tours" in the area, which served a critically important educational function. One agency, the California Air Resources Board, devoted substantial resources to information gathering.

What one can glimpse from this project is a strong sense that outsiders cannot build a collaborative process, no matter how well-intentioned or talented the participants might be. Community members persevered through several years of frustrations and setbacks because they had a trusted alliance with an organization with a good track record. The facilitator did not allow powerful economic stakeholders to dominate the process with endless debates about evidence and instead focused on the goals and means to acquire needed information and reduce pollution loads. The project survived because the goal-protecting children's health-was something all participants viewed as important enough to work through difficult issues.

A basin institution, even if it has plenary legal authority, will be successful only if participants can trust that the process has true integrity. If

74. Id. at 412 .

75. For a report of this meeting, see ICMA, ForUm ON BUILDING COLLABOrative Models to Achieve Environmental Justice-May 17 \& 18 , 2001, Chevy Chase, Maryland (2002). 
it is dominated by powerful water interests, the result will be a continuation of water wars and litigation. Or if the basin authority proceeds with a single-focus mission to protect the water resource ecologically without due consideration of the social costs that might be generated, the result will be the displacement of communities. One way to attempt to avoid these unintended consequences is to pursue aggressively capacity building and collaborative approaches. As important as these procedural approaches are, however, they may have limited value if the laws favor unfettered market approaches to water allocation and pollution control.

One of the most promising substantive standards in water law is the requirement, adopted by several states, that a request for water allocation or transfer should be approved only if it is consistent with the public welfare. This criterion should be fully developed. The standard is insufficient if a determination that allocated or transferred water will be put to a beneficial use is a per se satisfaction of the public welfare standard. A more nuanced analysis should be applied. For example, the basin institution can consider who is primarily benefitted from the water transfer and who is burdened, and in particular its effect on rural economic development. ${ }^{76}$ Another set of criteria could be developed for a transfer's effect on land-based religious practices or long standing traditions. Environmental laws have similar standards that can be used; for example, permitting provisions contain omnibus authority to consider such things as "the protection of health," "the protection of welfare," or the "social costs" imposed as a result of a facility's location or processes."

76. In the acequia context, attomey Benavidez proposes the following criteria for proposed transfers:

- Does only one person benefit in the move-from community or do many people?

- Is whatever benefit occurs a one-time benefit or does [sic] benefits recur over time?

- Is the water right severed from the community or does ownership remain in the community?

- Is the new economic activity flowing from the water right occurring in the community or is it removed from the community?

- Does the transaction contribute to the economic development of the community or does the transaction perpetuate, or even worsen the state of underdevelopment that existed?

- Is agricultural land taken out of production or not?

Benavidez, supra note 23.

77. See Gauna, supra note 11, at 10538, for a discussion of the use of this authority. 
Land use provisions such as buffer zones and development restrictions can also be used; planning tools such as impact statements and planned growth strategies can be required and given substantive effect. ${ }^{18}$ All of these mechanisms can and should be used to fairly balance the ecological needs of the basin with the anticipated economic and social costs.

\section{Conclusion}

In the final analysis, in order for a basin institution to accomplish what institutions have failed to do thus far, it will have to self-consciously confront fundamental ideological conflicts such as whether water is primarily a public resource or primarily for economic exploitation, whether all interests are on equal footing or whether there are some interests - such as rights of minority populations or the sovereignty of tribes-that should receive maximum protection, and whether the institution will adhere to the principle of an unfettered market or not. The basin institution must necessarily adopt a mission much broader than one of protecting the water basin's ecological integrity. It must do so without further injury to vulnerable populations, without displacement of old communities, and without further impairment of tribal sovereignty and self-determination. Enhancing ecosystem integrity and doing so without generating these social costs is certain to run up against the enduring expectations of powerful interest groups that have controlled water use for generations. One way to promote ecological sustainability in a socially responsible manner is to create an institution that commits resources to building participatory capacity, develops a tradition of respect for the experience and knowledge of populations historically tied to the river system, uses well-thought out collaborative approaches, and uses legal standards and discretionary authority in a courageously protective manner. It is only when difficult social issues are confronted, not only in design but also in ongoing implementation, that the promise and civil potential of a true dryland democracy can be realized.

78. See Amold, supra note 57. 